\title{
1 Escape rate for cod (Gadus morhua) from the codend during buffer
}

2 towing

3 Jesse Brinkhof ${ }^{1^{*}}$, Bent Herrmann ${ }^{1,2}$, Roger B. Larsen ${ }^{1}$, Manu Sistiaga ${ }^{3}$

$4 \quad{ }^{1}$ Norwegian College of Fishery and Aquatic Science, University of Tromsø, 9037 Breivika, Tromsø, Norway

$5 \quad{ }^{2}$ SINTEF Ocean, Fishing Gear Technology, Willemoesvej 2, 9850 Hirtshals, Denmark

${ }^{3}$ SINTEF Ocean, Fishing Gear Technology, Brattørkaia 17C, N-7010 Trondheim, Norway

* Corresponding author, Tel. +47 97662167; Email: jesse.brinkhof@uit (J. Brinkhof)

\section{Abstract}

The high abundances of Northeast Arctic cod (Gadus morhua) in the Barents Sea have led to the development of a new fishing tactic called buffer towing. On factory trawlers, the trawl is deployed immediately after taking the catch onboard, a tactic used to ensure a continuous supply of fish is being processed. If the desired amount of fish is caught before the catch from the previous haul has been fully processed, the trawl is lifted off the seabed and towed at a given depth at low speed. This is called buffer towing. Cod that escape from the codend when the trawl is shallower than the initial fishing depth are exposed to an increased likelihood of barotrauma-related injuries, increased disease susceptibility, and predation, which could be lethal, or affect growth and reproduction capability. Therefore, this study quantified the escape rate and size selectivity during buffer towing of cod. A new analytical method was applied that allows using the same trawl configuration as applied during commercial fishing and avoids potential bias in the assessment of buffer towing size selection. Our results demonstrated a significant size selection for cod during buffer towing where cod measuring up to at least 42 $\mathrm{cm}$ in length were proven to escape. In particular, at least $60 \%$ of cod measuring $20 \mathrm{~cm}$ were estimated to escape during buffer towing. For cod measuring $30 \mathrm{~cm}$ and $40 \mathrm{~cm}$, at least $53 \%$ and $45 \%$ were estimated to escape during buffer towing, respectively.

Keywords: buffer towing, cod, demersal trawl, escape rate, selectivity.

\section{Introduction}

The stock of Northeast Arctic cod (Gadus morhua L.) is currently the largest cod stock in the world and it is the most important fishery in the Barents Sea (Yaragina et al., 2011). The annual total allowable catch for cod in 2016 was 894,000 metric tons (ICES, 2016), and the current stock level is anticipated to remain stable in future years (ICES, 2015). On average, about 70\% 
of this stock is caught with bottom trawls. High abundances and dense aggregations of cod frequently lead to large catches (20-30 metric tons) during relatively short towing times (i.e. 15-30 minutes). Despite these catches, many skippers choose to deploy the trawl directly after taking the catch onboard. The rationale for this practice onboard factory trawlers is to maintain a continuous supply of fish into the processing facilities. The towing time required to refill the trawl is often unpredictable and unknown, and the approximate required amount of cod is frequently caught before the catch from the previous haul has been processed. Thus, to avoid excessively large catches, the trawl is lifted from the seabed and towed at a given depth (30-70 $\%$ of maximum depth) at low speed, usually $~ 1-2$ knots, until the factory capacity is restored onboard. We refer to this practice as "buffer towing" but it is known as "shortwiring" in the Alaska pollock trawl fishery (Dietrich and Melvin, 2007; Norwegian Directorate of Fisheries, 2013).

Buffer towing is controversial because of three main reasons. First, buffer towing might reduce the quality of the cod catch due to elevated levels of stress, barotrauma related injuries and suffocation amongst others. Second, it may lead to mortality of cod (Norwegian Directorate of Fisheries, 2013) and the Norwegian coast guard has documented fish floating on the surface behind trawlers engaged in buffer towing (Norwegian Directorate of Fisheries, 2013). Third, buffer-towed catches contain fewer undersized fish compared with catches that are taken directly onboard (Norwegian Directorate of Fisheries, 2013), thereby indicative of cod selection by size during buffer towing. Previous studies have documented a significant selection process during haul-back and at the surface for both demersal trawls (Madsen et al., 2008; Grimlado et al., 2009; Herrmann et al., 2013), and demersal seines (Isaksen and Løkkeborg, 1993). Therefore, it is reasonable to expect that the same would occur during buffer towing.

The quantity and survivability of fish that escape from the codend during buffer towing are not known. Several studies have documented negligible immediate mortality among cod escaping from demersal trawls at the seabed (Soldal et al., 1993; Suuronen et al., 1995; Ingólfsson et al., 2007), but to the best of our knowledge, no studies have investigated the survivability of fish escaping during haul-back, buffer towing, or at the surface (Madsen et al., 2008). Many factors are known to affect the survivability of fish escaping from trawls, including biotic and abiotic factors, e.g., stress increasing the risk of predation or susceptibility to disease, behavioral impairment, scale damage with possible subsequent osmotic disturbances or infections, barotrauma, or other types of injuries inflicted upon fish during the catch or escape processes (DeAlteris and Reifsteck, 1993; Soldal et al., 1993; Chopin and Arimoto, 1995; Suuronen et 
al., 1995; Davis, 2002; Ryer, 2002; Ryer et al., 2004; Suuronen et al., 2005; Humborstad and Mangor-Jensen, 2013; Rankin et al., 2017). Therefore, if fish that escape do not survive, stock health may be compromised and fishing mortality (F) underestimated due to unaccounted mortality of escaped cod. Moreover, the fish that escape during buffer towing measuring more than the minimum landing size (currently $44 \mathrm{~cm}$ for cod north of $62^{\circ} \mathrm{N}$ ) represent a loss of marketable catch.

The main objective of this study was to determine whether a selective process occurs during buffer towing. In particular, we addressed the following research questions.

- Does size selection occur during buffer towing?

- If size selectivity does occur during buffer towing, then what are the sizes of the cod that escape and what is their escape rate?

\section{Materials and methods}

\section{Sea trials and trawl rigging}

Experimental fishing was conducted onboard the research trawler R/V “Helmer Hanssen” (63.8 $m$ and 4080 HP) during November 10-29 2016, in the central area of the Barents Sea (N7459'N75²6'; E30 $\left.{ }^{\circ} 54^{\prime}-E 31^{\circ} 17^{\prime}\right)$. The trawl employed was a two-panel Alfredo 3 trawl built entirely of $150 \mathrm{~mm}$ polyethylene meshes. The trawl configuration was comparable to the configuration used in the commercial fishery. We used Injector Scorpion otter boards (each weighing 3100 $\mathrm{kg}$ and measuring $8 \mathrm{~m}^{2}$ ), which were equipped with $3 \mathrm{~m}$-long backstraps and linked to the sweeps with a $7 \mathrm{~m}$ chain. The sweeps measured $60 \mathrm{~m}$ in length and they were equipped with a $\varnothing 53-\mathrm{cm}$ steel bobbin at the center to protect the sweeps from excessive abrasion. The ground gear was $46.9 \mathrm{~m}$ in length and comprised a $18.9 \mathrm{~m}$-long rockhopper gear with Ø 53-cm discs in the center, and a $14 \mathrm{~m}$ chain (Ø $19 \mathrm{~mm}$ ) on each side equipped with three steel bobbins (Ø 53 $\mathrm{cm})$. A sorting grid made of stainless steel was inserted between the codend and the trawl belly. To reduce catches of cod below the minimum landing size of $44 \mathrm{~cm}$, a grid with a minimum bar spacing of $55 \mathrm{~mm}$ is compulsory for the demersal trawl fishery in the Northeast Atlantic. The four-panel codend (mesh size $132.1 \pm 2.6 \mathrm{~mm}$ (mean $\pm \mathrm{SD}$ )) was mounted to the grid section, where it was preceded by a transition section from 2 to 4 panels. Since the mesh size, and codend configuration is regulated by law, this codend is representative for the entire trawl fleet in the Barents Sea. To control the catch size and standardize tow duration, we inserted an excessive fish excluder device, i.e., a release mechanism in the anterior part of the codend (Grimaldo et al., 2014). The excessive fish excluder device consists of a fish lock with escape 
opening(s) in front. The fish lock was built of netting with $80 \mathrm{~mm}$ mesh size, and oblique cut from 152 meshes in circumference in the anterior part down to 72 meshes in the aft part. The anterior part was sewn into the codend 20 meshes in front of the codline, which was equivalent to approximately 2 metric tons of catch. We made a hole in both side panels of the codend in front of the fish lock to release all the excessive fish caught after the codend is filled up to the fish lock. The trawl was monitored using the following sensors obtained from Scanmar: sensors for measuring the door spread, trawl height, and a trawl eye for measuring the towing depth during buffer towing in the water column.

\section{Experimental method}

We were only interested in detecting possible size selection during buffer towing, so a covered codend setup was not convenient because it would have collected fish escaping during regular towing on the seabed. Furthermore, there would have been a possibility of escaping fish reentering the codend from the cover when using a covered codend at a relative low speed. A cover might also potentially affect the behavior of the codend during buffer towing, thereby influencing the probability of fish escaping during this process. Therefore, in addition to the technical challenge of using a direct sampling method with a cover for collecting the fish that escaped during buffer towing (Madsen and Holst, 2002), it is possible that this method could lead to biased estimates. Employing a multi-sampler, a system that is acoustically triggered to open and close covers on a trawl, could only partly solve these issues (Madsen et al., 2008; Grimaldo et al., 2009). Therefore, we used an indirect method to assess the fish escape rate during buffer towing. In particular, employing the same trawl, we alternated and compared the hauls with a normal haul-back where the catch was taken directly onboard and hauls where the trawl was lifted off the seabed and buffer towed (Fig. 1). The cod lengths (total length) of the entire catch in each haul were measured to the nearest lower centimeter. By comparing the catches from the hauls with and without buffer towing, we indirectly quantified the escape probability for fish during buffer towing using a model developed specifically for this purpose (Section 2.2). The towing time on the seabed for hauls with the regular haul-back procedure was limited to $2 \mathrm{~h}$. Hauls with buffer towing lasted for $3 \mathrm{~h}$, where the trawl was towed at the seabed for 2 h. Buffer towing was conducted by lifting the trawl to a depth approximately $40 \%$ of the towing depth. Since the depth were buffer towing is conducted by factory trawlers varies, this depth was chosen as an average depth reduction, based on personal experience with trails onboard commercial trawlers. This depth-ratio is believed to be the most commonly employed 
depth for buffer towing in commercial operations, i.e., sufficiently shallow to avoid continuous

129 fishing but deep enough to prevent the swim bladders from bursting.

130 Model for assessing size selection during buffer towing

131 The size selectivity process during trawling can be regarded as a sequential process so the total

132 selectivity $r_{\text {normal }}(l)$ without buffer towing is:

$133 \quad r_{\text {normal }}(l)=r_{t}(l) \times r_{f}(l)$,

134 whereas with buffer towing, the total size selectivity $r_{\text {extended }}(l)$ is:

$135 r_{\text {extended }}(l)=r_{t}(l) \times r_{b}(l) \times r_{f}(l)$,

136 where $r_{t}(l)$ is the size selection during towing at the fishing depth and the haul-back up to the depth where buffer towing begins, $r_{f}(l)$ is the size selectivity from the depth of buffer towing

138 to the surface as well as the selectivity at the surface, and $r_{b}(l)$ is the size selectivity during

139 buffer towing.

140 Let $n n_{l i}$ and $n_{l j}$ be the numbers of fish in length class $l$ caught in the normal haul $i$ and the 141 buffer-towed haul $j$, respectively. Based on the group of $a$ normal hauls and the group of $b$ 142 buffer-towed hauls, we can calculate the experimental average catch comparison rate $C_{l}$

143 (Herrmann et al., 2017) as follows.

$144 \quad C C_{l}=\frac{\sum_{j=1}^{b} n e_{l j}}{\sum_{j=1}^{b} n e_{l j}+\sum_{i=1}^{a} n n_{l i}}$

145 The next step is to express the relationship between the catch comparison rate $C C(l)$ and the 146 buffer towing size selection process $r_{b}(l)$. Let us assume that the total amount of fish $n_{l}$ in 147 length class $l$ enter the codend of the trawl during one of the normal hauls or buffer-towed hauls 148 (Fig. 1.).

149 FIG. 1

150 SP is the proportion of fish entering the codend in the $a$ normal hauls compared to the in $a$ 151 normal hauls and the $b$ hauls with buffer towing which is assumed to be length independent.

152 Therefore, the expected values for $\sum_{i=1}^{a} n n_{l i}$ and $\sum_{j=1}^{b} n e_{l j}$, respectively, are:

153

$\sum_{i=1}^{a} n n_{l i}=n_{l} \times S P \times r_{\text {normal }}(l)$
$\sum_{j=1}^{b} n e_{l j}=n_{l} \times(1-S P) \times r_{\text {extended }}(l)$ 
154 Based on models (1) to (4) and Fig. 1, the theoretical catch comparison rate $C C(l)$ becomes:

$C C(l)=\frac{n_{l} \times S P \times r_{t}(l) \times r_{b}(l) \times r_{f}(l)}{n_{l} \times S P \times r_{t}(l) \times r_{b}(l) \times r_{f}(l)+n_{l} \times(1-S P) \times r_{t}(l) \times r_{f}(l)}=\frac{S P \times r_{b}(l)}{S P \times r_{b}(l)+1-S P}$.

156

157 After rearranging equation (5), we obtain the following.

158

$r_{b}(l)=\frac{1-S P}{S P \times(1-C C(l))}$

159

160

161

162

163

164

165

166

167

168

169

170

171

172

173

174

175

176

177

178

179

180

Thus, we have obtained a direct relationship between the buffer towing selectivity and the catch comparison rate, and in principle, we can assess the buffer towing selectivity based on the catch comparison data.

We estimated the average buffer towing size selectivity using maximum likelihood methods by minimizing the following equation with respect to the parameters describing $C C(l)$, which in addition to $S P$, includes the parameters in the model that we apply to $r b(l)$.

$-\sum_{l}\left\{\sum_{j}^{b}\left\{n e_{l j} \times \ln (C C(l))\right\}+\sum_{i}^{a}\left\{n n_{l i} \times \ln (1-C C(l)\}\right\}\right.$

Traditionally, size selectivity for diamond mesh codends was described using a traditional logit size selectivity model (Wileman et al., 1996):

$r_{\text {logit }}\left(l, l_{50}, S R\right)=\frac{\exp \left(\frac{\ln (9)}{S R} \times\left(l-l_{50}\right)\right)}{1+\exp \left(\frac{\ln (9)}{S R} \times\left(l-l_{50}\right)\right)}$,

where $L 50$ is the length of fish with a $50 \%$ probability of being retained during the selection process and SR is L75-L25. Thus, we adapt model (8) as a starting point. However, we also consider the potential situation where only a fraction of the fish in the codend are capable of attempting to escape during buffer towing, which is obtained by considering the assumed length-independent contact parameter $C$ (Herrmann et al., 2013), as follows.

$r_{C l o g i t}\left(l, C, l_{50}, S R\right)=1-C+C \times r_{\text {logit }}\left(l, l_{50}, S R\right)=1-\frac{C}{1+\exp \left(\frac{\ln (9)}{S R} \times\left(l_{50-l}\right)\right)}$

However, without assuming any specific model for the buffer towing selectivity, such as equations (8) or (9), we could formally determine whether there is evidence for size selectivity due to buffer towing by analyzing the catch comparison data. The null hypothesis was that no escapes occurred during buffer towing, which implies that $r_{b}(l)=1.0$ for all $l$, and thus based on equation (5), $C C(l)=S P$. Therefore, we first tested whether this hypothesis could be rejected based on the collected data by estimating the value of SP under this hypothesis (equation 7), 
and then calculating the $p$-value to obtain at least as big discrepancy as observed between the experimental catch comparison data and the model by chance. If this $p$-value was below 0.05 , we then rejected the null hypothesis unless the data appeared to exhibit over-dispersion by inspecting if there is any fish length dependence pattern in the deviation between the modeled catch comparison rate and the experimental data points. If the null hypothesis was rejected, thereby providing evidence for buffer towing size selectivity, then we quantified this selectivity with models (8), (9), and (5). This process included testing whether using models (8) and (9) in (5) could describe the observed catch comparison data sufficiently well ( $p$-value $>0.05$ ), where we employed these models to estimate the parameters with equation (7). The parameters $S P$, $L 50$, and $S R$ were estimated with equation (8), and the estimation in equation (9) included the additional parameter $C$. If both equations (8) and (9) could describe the experimental data, then that with the lowest Akaike's information criterion (AIC) value (Akaike, 1974) was selected for modeling the buffer towing size selectivity. Also, both models are structural models, and are thus robust for extrapolations outside the range of the length classes that were measured (Santos et al., 2016). We estimated 95\% confidence intervals (CIs) for the catch comparison curve and the resulting buffer towing size selection curve using double bootstrapping for unpaired catch comparison data (Sistiaga et al., 2016). We performed 1000 bootstrap replicates.

All estimates were obtained using the software tool SELNET, which was developed for estimating the size selectivity and catch comparisons for fishing gears (Herrmann et al., 2013). The estimations were then exported and graphically represented using R (R Core Team, 2013).

\section{Fall-through}

Fall-through experiments were performed to assess the potential size selectivity in the codend. The length of each sample fish was measured and tested in a vertical direction under the influence of gravity to determine whether it would fall through the meshes or not (see Herrmann et al. (2009) for further information about this methodology). Besides, the mesh opening angle varies during fishing according to the state of the mesh (stiff or slack), which affects the size selective potential of codend meshes (Herrmann et al., 2016). Therefore, we carried out fallthrough experiments for four different codend mesh scenarios. The codend was stretched to obtain different opening angles, which were approximately $35^{\circ}, 60^{\circ}$ and $90^{\circ}$ opening angle, as well as for a slack mesh (a slack mesh is flexible, and not in a stretched position). These, four mesh scenarios were assumed to represent the potential variation in the mesh openings encountered during fishing, and thus cover the size selective potential of the codend during buffer towing, including the potential effects of codend catch weight, position along the codend, 
214 and sea state (O'Neill and Herrmann, 2007). The purpose of these fall-through experiments 215 were to provide approximate limits for the sizes of cod that potentially could be subjected to 216 size selection in the codend during buffer towing. Knowing these limits will help the 217 interpretation of the results being obtained from the experimental fishing.

218 The data obtained from the fall-through experiments for each mesh scenario was analyzed 219 separately as covered codend data, and a logit selection model (8) was fitted to the data using 220 SELNET. We estimated LO5 and L95, which denote the lengths of cod with 5\% and 95\% 221 likelihoods of being retained, respectively (i.e., not passing through the codend meshes) to represent the approximately size range for cod that potentially could be subjected to a size selection process during buffer towing. Therefore, among the four mesh scenario's tested, we selected the one with the highest L95 value to represent the upper size limit, where only very few cod above that limit had the potential to escape during buffer towing. Likewise, we used the mesh scenario leading to the lowest L05 value to represent the lower size limit for cod at which the codend meshes begin to restrict escapement of some cod.

Using the logit size selection model (8), we calculated the 5\% and 95\% probability of retention by setting $(l, r(l))$ to $(L 05,0.05)$ and $(L 95,0.95)$, respectively, and then solving the equations with respect to L05 and L95 (Krag et al., 2015). The simple calculations yielded the following.

$L 05=L 50-S R \times \frac{\ln (19)}{\ln (9)}$

$L 95=L 50+S R \times \frac{\ln (19)}{\ln (9)}$

\section{Results}

233 Data

234 We completed a total of 20 alternating hauls, where 10 were conducted as regular hauls, i.e., 235 taking the catch directly onboard, and 10 as buffer hauls (Table 1). The area, towing time, 236 towing depth, and buffer-towing depth were kept as constant as possible to reduce between237 haul variation, and we also ensured that the samples were taken from the same population of 238 fish. (Fig. 2, Table 1). Subsampling was not performed and the lengths of 7670 cod were 239 measured, including 4887 obtained from the hauls with buffer towing.

240 FIG. 2

241 TABLE 1 
243 Fall-through experiments were conducted with $82 \mathrm{cod}$, which were sampled randomly from the 244 codend in the size range between $34 \mathrm{~cm}$ and $72 \mathrm{~cm}$. The fish were tested on slack meshes and through three different mesh openings; $35^{\circ}, 60^{\circ}$, and $90^{\circ}$. The codend employed was the same as that used in the fishing trials. The fall-through size selectivity curves (Fig. 3) and the values of L05 and L95 (Table 2) indicated that the codend could release cod in the size range encountered during the cruise.

249 FIG. 3

TABLE 2

\section{Model selection}

252 The length distributions for cod caught during the regular hauls with direct haul-back and the 253 extended hauls with buffer towing are presented in Fig. 4a. The null hypothesis model $\left(\mathrm{H}_{0}\right)$ had

254 a p-value well below 0.05 (Table 3), so it was highly unlikely that this model was valid, thereby 255 implying that size selection occurred during buffer towing. Figure 4b shows the fit of the $\mathrm{H}_{0}$ 256 model to the data, which indicates a clear length-dependent pattern in the differences between 257 the model and data. Contrary, both the Logit and Clogit models for the buffer-towing selection 258 result in p-values that makes it highly likely that the discrepancy between observed data and 259 fitted model is a coincidence (Table 3).

\section{TABLE 3}

261 The experimental catch comparison rates presented in Fig. 4b clearly differ from the black line 262 representing $\mathrm{H}_{0}$, thereby confirming that the null hypothesis should be rejected. Comparing the 263 catch comparison curve in Fig. 4b with Fig. 4c, visualizes this difference even more, while the latter catch comparison curve nicely follows the experimental data points, the catch comparison curve for the $\mathrm{H}_{0}$ model clearly deviates. Since the $\mathrm{H}_{0}$ model is a length independent catch comparison rate, the value of 0.64 is equal to that of the split parameter (SP). The two models (8) and (9) both obtained catch comparison curves that agreed well with the trends in the experimental data, without any length-dependent patterns in the differences (Fig. 4c).

269 In fact, both models obtained identical curves but the AIC value was higher for the Clogit model 270 (Table 3). Thus, we selected the logit model to describe the size selectivity during buffer towing. 271 According to the AIC values, $\mathrm{H}_{0}$ could be rejected because the AIC value was higher than that 272 for the logit and the Clogit model. Using the method described by Herrmann et al. (2016), the 
273 relative likelihood between $\mathrm{H}_{0}$ and the logit model indicated that there was an $8.96 \times 10^{-7} \%$

274 probability of $\mathrm{H}_{0}$ being extremely unlikely.

$275 \quad$ FIG. 4

276 Escape rate during buffer towing

277 The vertical line on the right-hand side in Fig. 5 represents the upper limit (L95) for potential 278 escapes by cod, which shows that minimal mesh size selection occurred to the right-hand side 279 of this vertical line (95\% retention rate). The results from the fall through experiments proved 280 that this upper limit (L95) for potential escapes was achieved with slack meshes (Table 2). 281 However, the vertical line on the left-hand side represents the lower limit (LO5), which shows 282 that most cod below this limit had the potential to escape (5\% retention rate) (Fig. 5). For the 283 lower limit (LO5), the results from the fall through experiments proved that meshes with a $60^{\circ}$ 284 opening angle had the lowest retention probability (Table 2). Table 4 shows the parameters and 285 estimated retention probabilities for specific sizes of cod, which proves that selection occurred 286 for cod measuring up to at least 40-42 cm (Fig. 5, Table 4). We cannot prove any size selection above $42 \mathrm{~cm}$ since the upper $\mathrm{CI}$ is equal to 1 , however the size selection curve indicates a selection process also for cod above $42 \mathrm{~cm}$ (Fig. 5).

FIG. 5

TABLE 4

The size selection curve demonstrates that a large proportion of the undersized cod measuring 292 up to at least $40 \mathrm{~cm}$ that were located in the codend when buffer towing was initiated will escape during buffer towing.

294 The most conservative estimate, i.e., the upper CI for the retention rate represented by the size selection curve (i.e., lower CI when considering the escape rate), proves a strongly lengthdependent buffer towing escape rate (Fig. 5). In particular, the upper CI of the retention curve proves an escape rate of $64 \%$ for cod measuring $20 \mathrm{~cm}$, which declined to $46 \%$ for cod measuring $40 \mathrm{~cm}$ (Fig. 5, Table 4). Thus, the number of escapes may have been high in terms of the number of fish, depending on the amount of cod in this size range that remained in the codend before buffer towing was initiated. The size selection curve provides evidence for the escape of cod up to at least $42 \mathrm{~cm}$ (Fig. 5).

\section{Discussion}


303 From a fishing industry perspective, buffer towing is controversial because it might reduce the 304 quality and the value of the catch. From a management viewpoint, buffer towing is considered to contribute to unaccounted mortality, with the consequences this entails for stock recruitment and stock health, as well as the productivity of the fishery. This study showed that considerable numbers of cod measuring at least $42 \mathrm{~cm}$ may escape during buffer towing. Due to wide CI's we cannot prove escapement for cod above this size, however, the size selectivity curve shows that it is highly likely that cod above $42 \mathrm{~cm}$ escape during buffer towing. This, is further supported by the results from the fall-through experiments showing potential codend size selection for cod up to at least $54 \mathrm{~cm}$ (lowest L05) and at most up to $64 \mathrm{~cm}$ (highest L95). Therefore, the number of escaping cod can be high, depending on the amount of cod in the selective size range that remain in the codend before buffer towing is initiated. Furthermore, the most conservative selectivity estimate, i.e., the upper CI limits for the retention rate (Table 4), proves a length-dependent escape rate during buffer towing of at least $64 \%$ for cod measuring $20 \mathrm{~cm}$, which declines to at least $46 \%$ for cod measuring $40 \mathrm{~cm}$. Thus, our findings support the claims of the Norwegian coast guard and management authorities who claimed that catches from vessels that have buffer towed contained fewer undersized fish compared with catches taken directly onboard. In addition, our results indicated that buffer towing can lead to losses of cod above the minimum landing size of $44 \mathrm{~cm}$, and thus losses of the valuable marketable catch for the fishing vessel. This is illustrated by an estimated escape probability at $59 \%$ for cod at the minimum landing size (Table 4); however, we can only prove escape of cod to $42 \mathrm{~cm}$, due to wide CI’s.

The experimental design employed in this study was challenging because few sampling designs could have been used to address the research questions. However, the use of these traditional direct methods such as a cover codend setup or a multi-sampler may have led to biased estimates and results due to the possibility of fish re-entering the codend, as well as the cover affecting the behavior of the codend. Therefore, we developed a novel indirect method to assess the selection during buffer towing as the research questions address. In contrast to traditional direct methods, i.e., measuring the absolute quantity of escaping fish, our method can calculate the rate of cod escaping during buffer towing, and thus it is may be applied to other scenarios for the same species population. This method can also be applied for any other species requiring relative comparison of catch rates. However, a disadvantage of this indirect method is that it requires robust data, which can be obtained by increasing the number of hauls in order to achieve narrow CIs. An advantage of this method is that it allows buffer towing to be 
investigated without making changes to the trawl. Hence, the application of this method is especially advantageous for this type of research on commercial fishing vessels, where the possibility of modifying the trawl is often limited or impossible. Further, by avoiding covers or any other changes of trawl gear between the hauls, this method can potentially increase the sampling efficiency, as no time is lost for making gear changes or handling covers. In addition to avoiding the problem of biased estimates and changes in the trawls, it could easily be applied to investigate similar issues, such as investigating other typical bycatch species in the same fishery, including haddock (Melanogrammus aegefinus), saithe (Pollachius virens), or redfish (Sebastes spp.), as well as in other similar fisheries where buffer towing is applied such as the Alaska trawl fisheries (Dietrich and Melvin, 2007).

Fish escapes during buffer towing have two main impacts. One impact is caused by the escape of legal sized cod which leads to less efficient harvesting, due to loss of marketable catch, and thus reduced catch per unit effort. However, this study could not prove whether there was any selection above the minimum landing size for cod because of the broad CI obtained. However, the results of the fall-through experiments determined the limits for size selection in the four different mesh scenarios with the codend employed, which showed that it is highly likely that size selection also occurred for fish above the minimum landing size during buffer towing. In addition, it is highly probable that the CI's would become narrower by increasing the number of hauls, thereby demonstrating the statistically significant size selectivity for fish above the minimum landing size. The second impact of fish escapes during buffer towing is the escape of fish below the minimum landing size, which this study proved. The escapement of fish below the minimum landing size is usually regarded as a positive improvement in the overall size selectivity, but its effect depends on the fate of the escapees. Thus, buffer towing would reduce the unintended mortality if the escaping fish survive, whereas it would contribute to increased unintended and unaccounted mortality if the escaping fish do not survive.

In general, fish caught by trawling are likely to sustain barotrauma-related injuries, exhaustion, stress, and behavioral impairment during trawling at the seabed as well as during the haul-back procedure (DeAlteris and Reifsteck, 1993; Soldal et al., 1993; Chopin and Arimoto, 1995; Suuronen et al., 1995; Suuronen et al., 2005; Midling et al., 2012; Rankin et al., 2017). Several studies have documented the high survival rate of cod escaping demersal trawls at the seabed (Soldal et al., 1993; Suuronen et al., 1995; Ingólfsson et al., 2007), but no studies have investigated the survival of cod escaping during haul-back, during buffer towing, or at the surface (Madsen et al., 2008). Cod possess a physoclist swim bladder, so a rapid ascent can 
369

370

371

372

373

374

375

376

377

378

379

380

381

382

383

384

385

386

387

388

389

390

391

392

393

394

395

396

397

398

399

400

result in a rapid increase in positive buoyancy, and possible over inflation and bursting of the swim bladder. Since a deflated swim bladder is sealed immediately after bursting, and the prerupture strength is regained within four days, Midling et al., (2012) and Humborstad and Mangor-Jensen, (2013) argue that such an injury in itself is considered to be relatively benign with a rapid recuperation time. However, the natural behavior of cod with a ruptured swim bladder is to dive toward the seabed, which entails negative buoyancy, and this is likely to affect the rate of mortality due to behavioral impairment increasing the risk of predation (Nichol and Chilton, 2009; Midling et al., 2012). If the reduction in depth is small, the fish may partly decompress during buffer towing before escaping. However, if the swim bladder is initially underinflated, due to vertical diurnal migration, the rate of overinflation will be too small to make the swim bladder burst, preventing the fish from returning to its original depth and enhance the probability of "floaters" (i.e., fish usually found floating upside down on the surface) with a lethal outcome (Midling et al., 2012). Therefore, the depth at which trawlers buffer tow will probably affect the survival rate of any fish escaping during the process. In general, fish sustain various types of injuries during the catching or escape process, such as stress, behavioral impairment, scale damage with possible subsequent osmotic disturbances or infections, barotrauma-related injuries, or other types of injuries. These factors are known to cause long-term delayed mortality due to the elevated risk of predation and susceptibility to disease (Chopin and Arimoto, 1995; Davis, 2002; Ryer, 2002; Ryer, 2004; Ryer et al., 2004). It is likely that buffer towing increases the risk of the above mentioned injuries, and it is therefore highly probable that buffer towing contributes to unaccounted fishing mortality.

In this study, we demonstrated the occurrence of a significant size selection process during buffer towing, which differs from normal tow procedures. Therefore, we suggest that the survivability of any fish escaping during these capture processes as well as in haul-back and at the surface should be investigated further.

\section{Acknowledgments}

This study was part of the Centre of Research-based Innovation in Sustainable fish capture and Processing technology (CRISP) project funded by the Norwegian Research Council, Grant No. 203477. We are grateful for the effort and the highly appreciated comments from the editor and the two anonymous reviewers. We thank The Arctic University of Norway for financial support and the Norwegian Directorate of Fisheries for the necessary permits. We also thank Jure Brčić for help provided during the cruise. 


\section{References}

402

403

404

405

406

407

408

409

410

411

412

413

414

415

416

417

418

419

420

421

422

423

424

425

426

427

Akaike, H. 1974. A new look at the statistical model identification. IEEE Transactions on Automatic Control 19, 716-722.

Chopin, F.S., Arimoto, T., 1995. The condition of fish escaping from fishing gears-a review. Fish. Res. 21 (3-4), 315-327 http://dx.doi.org/10.1016/0165-7836(94)00301-C.

Davis, M. W., 2002. Key principles for understanding fish bycatch discard mortality. Canadian Journal of Fisheries and Aquatic Sciences, 59(11), 1834-1843, DOI: 10.1139/F02-139

DeAlteris, J. T., Reifsteck, D.M., 1993. Escapement and survival of fish from the codend of a demersal trawl. ICES Mar. Sci. Symp., 196: 128-131.

Dietrich, K.S., Melvin, E. F., 2007. Alaska Trawl Fisheries: Potential Interactions with North Pacific Albatrosses. WSG-TR 07-01, Washington Sea Grant, Seattle, WA

Grimaldo, E., Larsen, R. B., Sistiaga, M., Madsen, N., Breen, M., 2009. Selectivity and escape percentages during three phases of the towing process for codends fitted with different selection systems. Fish. Res., 95(2), 198-205. http://dx.doi.org/10.1016/j.fishres.2008.08.019

Grimaldo, E., Sistiaga, M., Larsen, R. B., 2014. Development of catch control devices in the Barents Sea cod fishery. Fisheries Research, 155, 122-126, https://doi.org/10.1016/j.fishres.2014.02.035

ICES, 2015. Report of the Arctic fisheries working group (AFWG), 2015, Hamburg, Germany. ICES CM 2015/ACOM: 05, 639 pp.

ICES, 2016. Cod (Gadus morhua) in subareas 1 and 2 (Northeast Arctic). ICES Advice on fishing opportunities, catch, and effort Barents Sea and Norwegian Sea Ecoregion, June 2016. http://www.ices.dk/sites/pub/Publication\%20Reports/Advice/2016/2016/codarct.pdf

Ingólfsson, Ó. A., Soldal, A. V., Huse, I., Breen, M., 2007. Escape mortality of cod, saithe, and haddock in a Barents Sea trawl fishery. ICES Journal of Marine Science: Journal du Conseil, 64(9), 1836-1844. doi: 10.1093/icesjms/fsm150 
Isaksen, B., Løkkeborg, S., 1993. Escape of cod (Gadus morhua) and haddock (Melanogrammus aeglefinus) from Danish seine codends during fishing and surface hauling operations. ICES Mar. Sci. Symp., 196: 86-91.

Herrmann, B., Krag, L., Frandsen, R., Madsen, N., Lundgren, B., Stæhr, K.J., 2009. Prediction of selectivity from morphological conditions: Methodology and case study on cod (Gadus morhua). Fisheries Research 97, 59-71, https://doi.org/10.1016/j.fishres.2009.01.002

Herrmann, B., Mieske, B., Stepputtis, D., Krag, L. A., Madsen, N., Noack, T., 2013 Modelling towing and haul-back escape patterns during the fishing process: a case study for cod, plaice, and flounder in the demersal Baltic Sea cod fishery. ICES Journal of Marine Science, 70: 850-863, doi.10.1093/icesjms/fst032.

Herrmann, B., Larsen, R.B., Sistiaga, M., Madsen. N.H.A., Aarsæther, K.G., Grimaldo, E., Ingolfsson, O.A., 2016. Predicting Size Selection of Cod (Gadus morhua) in Square Mesh Codends for Demersal Seining: a Simulation-based Approach. Fisheries Research 184, 36-46, https://doi.org/10.1016/j.fishres.2015.07.015

Herrmann, B., Sistiaga, M., Rindahl, L., Tatone, I., 2017. Estimation of the effect of gear design changes on catch efficiency: Methodology and a case study for a Spanish longline fishery targeting hake (Merluccius merluccius). Fisheries Research, 185, 153-160, https://doi.org/10.1016/j.fishres.2016.09.013

Humborstad, O-D., Mangor-Jensen, A., 2013. Buoyancy adjustment after swimbladder puncture in cod Gadus morhua: An experimental study on the effect of rapid decompression in capture-based aquaculture. Marine Biology Research, 9:4, 383-393, DOI: $10.1080 / 17451000.2012 .742546$

Madsen, N., Holst, R., 2002. Assessment of the cover effect in trawl codend selectivity experiments. Fisheries Research, 56(3), 289-301, https://doi.org/10.1016/S01657836(01)00330-7

Madsen, N., Skeide, R., Breen, M., Krag, L. A., Huse, I., Soldal, A. V., 2008. Selectivity in a trawl codend during haul-back operation - an overlooked phenomenon. Fisheries Research, 91: 168-174, http://dx.doi.org/10.1016/j.fishres.2007.11.016

Midling, K. Ø., Koren, C., Humborstad, O-D., Sæther, B-S., 2012. Swimbladder healing in Atlantic cod (Gadus morhua), after decompression and rupture in capture-based 
aquaculture, Marine Biology Research, 8:4, 373-379, DOI: 10.1080/17451000.2011.638640

Nichol, D. G., Chilton, E. A. 2006. Recuperation and behaviour of Pacific cod after barotrauma. ICES Journal of Marine Science, 63: 83-94, doi:10.1016/j.icesjms.2005.05.021

Norwegian Directorate of Fisheries, 2013. Teknisk arbeidsgruppe om fangstregulerende tiltak i trålfisker - Rapport fra en arbeidsgruppe med medlemmer fra næring, forskning, forvaltning og kystvakt. In Norwegian.

Olsen, S. H., Tobiassen, T., Akse, L., Evensen, T.H., Midling, K.Ø., 2013. Capture induced stress and live storage of Atlantic cod (Gadus morhua) caught by trawl: Consequences for the flesh quality. Fish. Res. 147, 446-453. http://dx.doi.org/10.1016/j.fishres.2013.03.009

O’Neill, F.G., Herrmann, B., 2007. PRESEMO- a predictive model of codend selectivity- a tool for fisheries managers. ICES Journal of Marine Science 64: 1558-1568, https://doi.org/10.1093/icesjms/fsm101

R Core Team, 2013. R: A language and environment for statistical computing. R Foundation for Statistical Computing, Vienna, Austria. URL http://www.R-project.org/

Rankin, P. S., Hannah, R. W., Blume, M. T., Miller-Morgan, T. J., Heidel, J. R., 2017. Delayed effects of capture-induced barotrauma on physical condition and behavioral competency of recompressed yelloweye rockfish, Sebastes ruberrimus. Fish. Res., 186, 258-268. http://dx.doi.org/10.1016/j.fishres.2016.09.004

Ryer, C. H., 2002. Trawl stress and escapee vulnerability to predation in juvenile walleye pollock: Is there an unobserved bycatch of behaviorally impaired escapees? Marine Ecology Progress Series, 232, 269-279.

_Ryer, C.H., 2004. Laboratory evidence for behavioural impairment of fish escaping trawls: a $\begin{array}{llllll}\text { review. } & \text { ICES } & \text { J. } & \text { Mar. } & \text { Sci. } & 61 \text { (7), 1157-1164, }\end{array}$ http://dx.doi.org/10.1016/j.icesjms.2004.06.004

Ryer, C. H., Ottmar, M. L., Sturm, E. A., 2004. Behavioral impairment after escape from trawl codends may not be limited to fragile fish species. Fisheries Research, 66: 261-269. doi:10.1016/S0165-7836(03)00197-8 
Santos, J., Herrmann, B., Mieske, B., Stepputtis, D., Krumme, U., Nilsson, H., 2016. Reducing flatfish bycatch in roundfish fisheries. Fisheries Research, 184, 64-73. https://doi.org/10.1016/j.fishres.2015.08.025

Sistiaga M., Herrmann B., Grimaldo E., O’Neill F.G., 2016. Estimating the selectivity of unpaired trawl data: a case study with a pelagic gear. Sci. Mar. 80(3): 321-327. doi: http://dx.doi.org/10.3989/scimar.04409.26B

Soldal, A. V., Engås, A., Isaksen, B., 1993. Survival of gadoids that escape from a demersal trawl. ICES mar. Sci. Symp., 196: 122-127

Soldal, A. V., Isaksen, B., Marteinsson, J. E., Engås, A., 1991. Scale damage and survival of cod and haddock escaping from a demersal trawl. ICES Fish Capture Committee C.M. 1991/B: 44.

Suuronen, P., Lehtonen, E., Jounela, P., 2005. Escape mortality of trawl caught Baltic cod (Gadus morhua) - the effect of water temperature, fish size and codend catch. Fisheries research, 71(2), 151-163. http://dx.doi.org/10.1016/j.fishres.2004.08.022

Suuronen, P., Lehtonen, E., Tschernij, V., Larsson, P. Q., 1995. Skin injury and mortality of Baltic cod escaping from trawl codends equipped with exit windows. ICES CM 1995/B:8 Fish Capture Committee.

Wileman, D. A., Ferro, R. S.T., Fonteyne, R., Millar, R. B. (Eds.) 1996. Manual of Methods of Measuring the Selectivity of Towed Fishing Gears. ICES Cooperative Research Report No. 215. 126 pp.

Yaragina, N. A., Aglen, A., Sokolov, K. M., 2011. 5.4 Cod, in: Jakobsen, T., Ožigin, V. K., (Eds.). The Barents Sea: ecosystem, resources, management: half a century of RussianNorwegian cooperation. Trondheim: Tapir Academic Press, pp. 225-270. 